\title{
SOLID POLYMER ELECTROLYTE MEMBRANES ON THE BASIS OF FLUOROSILOXANE MATRIX
}

\author{
Omari Mukbaniani 1, 2, ${ }$, Jimsher Aneli ${ }^{2}$, Tamara Tatrishvili 1, 2, \\ Eliza Markarashvili ${ }^{1,} 2$
}

https://doi.org/10.23939/chcht15.02.198

\begin{abstract}
Hydrosilylation reactions of 2,4,6,8-tetrahydro-2,4,6,8-tetramethylcyclotetrasiloxane $\left(\mathrm{D}_{4}{ }^{\mathrm{H}}\right)$ with 2,2,3,3,4,4,5,5-octafluoropentyl acrylate at 1:4.2 ratio of initial compounds catalysed by platinum catalysts have been studied and corresponding adduct $\mathrm{D}_{4}{ }^{\mathrm{R}^{\prime}}$ has been obtained. Ring opening polymerization of $\mathrm{D}_{4}{ }^{\mathrm{R}}$ in the presence of dry potassium hydroxide has been carried out and comb-type polymers with 2,2,3,3,4,4,5,5octafluoropentyl propionate side groups have been obtained. The synthesized product $\mathrm{D}_{4}{ }^{\mathrm{R}}$ and polymers were analyzed by FTIR, ${ }^{1} \mathrm{H},{ }^{13} \mathrm{C}$, and ${ }^{29} \mathrm{Si}$ NMR spectroscopy. The solid polymer electrolyte membranes have been obtained via sol-gel reactions of polymers with tetraethoxysilane doped with lithium trifluoromethylsulfonate (triflat) and lithium bis(trifluorosulfonyl)imide. It has been found that the electric conductivity of the polymer electrolyte membranes at room temperature changes in the range of $\left(1.9 \cdot 10^{-6}\right)-\left(5.9 \cdot 10^{-10}\right) \mathrm{S} \cdot \mathrm{cm}^{-1}$.
\end{abstract}

Keywords: hydrosilylation, polymerization, sol-gel reactions, polymer electrolyte membrane, spectroscopy, ion-conductivity.

\section{Introduction}

Solid polymer electrolyte membrane fuel cell is attracting much attention as a new power source for transportation, stationary, portable and consumer electronics power applications from the viewpoint of environmental and new energy issues [1-5].

Polymer electrolytes (PE) play an important role in electrochemical devices such as batteries and fuel cells. To achieve optimal performance, the PE must maintain a high ionic conductivity and mechanical stability at both high and low relative humidity. The polymer electrolyte

\footnotetext{
${ }^{1}$ Iv. Javakhishvili Tbilisi State University,

1, I. Chavchavadze Ave., 0179 Tbilisi, Georgia

${ }^{2}$ Institute of Macromolecular Chemistry and Polymeric Materials, Iv. Javakhishvili Tbilisi State University,

13, I. Chavchavadze Ave., 0179 Tbilisi, Georgia

omar.mukbaniani@tsu.ge

(c) Mukbaniani O., Aneli J., Tatrishvili T., Markarashvili E., 2021
}

also needs to have excellent chemical stability for long product life and robustness.

According to the prevailing theory, ionic conduction in polymer electrolytes is facilitated by the large-scale segmental motion of the polymer backbone and primarily occurs in the amorphous regions of the polymer electrolyte. Crystallinity restricts polymer backbone segmental motion and significantly reduces conductivity. Consequently, polymer electrolytes with high conductivity at room temperature have been sought through polymers which have highly flexible backbones and have largely amorphous morphology.

It is widely accepted that amorphous polymers with low glass transition temperatures $T_{g}$ and a high segmental mobility are important prerequisites, halogen, especially fluorine groups for high ionic conductivities. Formation of the grid like structures increases the mechanical properties of polymer-electrolytes [6-8].

The continuous interest to polymer electrolytes is motivated, in first instance, by their intrinsic safety, compared to liquid electrolytes. In addition, SPEs offer better resistance to lithium dendrites growth, thus opening the way to the use of metal lithium as anode in lithiummetal polymer batteries $[9,10]$.

Despite having favorable properties, such as low cost, low toxicity, and no flammability, the application of polymer electrolytes has been so far limited. This is due mainly to their low conductivity, which, in the case of classic PEO-salt complexes, is about $10^{-6} \mathrm{~S} \cdot \mathrm{cm}^{-1}$ at room temperature. As comparison, the estimated necessary conductivity for practical purposes is almost $10^{-3} \mathrm{~S} \cdot \mathrm{cm}^{-1}$ at operating temperature [10].

More recently, hybrid electrolytes have been developed by ring opening reaction of PEG-functionalized tetrasiloxane [11], by surface functionalization of silica or titania nanoparticles [12], by sol-gel process [13-15]. In some of these works, conductivities higher than $10^{-4} \mathrm{~S} \mathrm{~cm}^{-}$ ${ }^{1}$ at room temperature are reported, even without addition of any plasticizer $[13,15]$.

The polysiloxanes are amorphous systems. They are characterized with very low glass temperature, extremely high free volume and high segmental mobility 
and present best matrix for $\mathrm{Li}$-ion transportation. The high solubility of the corresponding salt in the polymer is another one factor for achievement of high ionconductivity. This condition is created by introduction to the polymer-electrolyte main chain or side group of such "host" donor group, as an ester oxygen imide group, halogen, especially fluorine groups. Formation of the grid like structures increases the mechanical properties of polymer-electrolytes.

The aims of our work were: i) synthesis of $\mathrm{D}_{4}{ }^{\mathrm{R}}$ type methylorganocyclotetrasiloxane with 2,2,3,3,4,4,5,5octafluoropentyl propionate side groups at silicon atoms; ii) polymerization of $\mathrm{D}_{4}{ }^{\mathrm{R}}$ in the presence of nucleophilic catalysts and obtaining comb-type polymers with 2,2,3,3,4,4,5,5-octafluoropentyl propionate side groups; iii) study of sol-gel reaction of polymers doped with lithium trifluoromethylsulfonate (triflate) and lithium bis(trifluorosulfonyl)imide; iv) investigation of ionconductivity of obtained solid polymer electrolyte membranes (SPEm).

\section{Experimental}

\subsection{Materials}

All synthetic manipulations were carried out under an atmosphere of dry dinitrogen gas using standard vacuum line Schlenk techniques. All solvents were de-gassed and purified prior to use according to standard literature methods: toluene, hexane, and tetrahydrofuran were distilled from sodium/benzophenone ketyl. All other reagents (Aldrich) were used as received or distilled prior to use.

2,4,6,8-tetrahydro-2,4,6,8-tetramethylcyclotetrasiloxane $\left(\mathrm{D}_{4}{ }^{\mathrm{H}}\right)$, Karstedt's catalyst $\left(\mathrm{Pt}_{2}\left[\left(\mathrm{VinSiMe}_{2}\right)_{2} \mathrm{O}\right]_{3}\right)-$ platinum(0)-1,3-divinyl-1,1,3,3-tetramethyldisiloxane complex $(2 \%$ solution in xylene), platinum hydrochloric acid (Aldrich), Pt/C (10\%), lithium trifluoromethylsulfonate (triflat) and lithium bis(trifluorosulfonyl)imide were purchased from Aldrich and used as received. Toluene was dried and distilled from sodium under atmosphere of dry nitrogen. Tetrahydrofuran (THF) was dried over and distilled from $\mathrm{K}-\mathrm{Na}$ alloy under an atmosphere of dry nitrogen.

\subsection{Characterization}

FTIR spectra were recorded on a Nicolet Nexus 470 machine with MCTB detector. ${ }^{1} \mathrm{H},{ }^{13} \mathrm{C}$ NMR and ${ }^{29} \mathrm{Si}$ NMR spectra were recorded on a Bruker ARX400 NMR spectrometer at a $400 \mathrm{MHz}$ operating frequency with $\mathrm{CDCl}_{3}$ as the solvent and an internal standard. Differential scanning calorimetric investigation (DSC) was performed on a Netzsch DSC 200 F3 Maia apparatus. Thermal transitions including glass transition tempe- ratures $T_{g}$ were taken as the maxima of the DSC peaks. The heating and cooling scanning rates were $10 \mathrm{~K} / \mathrm{min}$.

\subsection{Hydrosilylation Reaction of $\mathrm{D}_{4}{ }^{\mathrm{H}}$ 2,2,3,3,4,4,5,5-Octafluoropentyl Acrylate}

$1.2000 \mathrm{~g}, \quad(0.0049 \mathrm{~mol}) \quad$ of $2,4,6,8$-tetrahydro2,4,6,8-tetramethylcyclotetrasiloxane $\quad\left(\mathrm{D}_{4}{ }^{\mathrm{H}}\right) \quad$ were transferred into a $100 \mathrm{ml}$ flask under nitrogen using standard Schlenk techniques. High vacuum was applied to the flask for half an hour before the addition of 2,2,3,3,4,4,5,5-octafluoropentyl acrylate $\quad(6.0050 \mathrm{~g}$, $0.0209 \mathrm{~mol}$ ) in $3 \mathrm{ml}$ dry toluene and Karstedt's precatalyst solution $(20 \mu \mathrm{l})$. The homogeneous mixture was degassed and placed into an oil bath, which was previously set to $343-353 \mathrm{~K}$ and the reaction continued at $323 \mathrm{~K}$. The reaction was controlled by the decrease of intensity of active $\equiv \mathrm{Si}-\mathrm{H}$ groups [16]. After finishing reaction $0.1 \mathrm{wt} \%$ of activated carbon was added and refluxed for $2 \mathrm{~h}$ for deactivation of catalysts. All volatiles were removed by a rotary evaporation at $320-330 \mathrm{~K}$ and further evacuated under high vacuum for $10 \mathrm{~h}$ to isolate the colorless viscous compound $\mathbf{I}\left(\mathrm{D}_{4}{ }^{\mathrm{H}}\right) 6.6 \mathrm{~g}(91.6 \%)$.

FTIR $\left(\mathrm{KBr}, \mathrm{cm}^{-1}\right) v_{\text {as }}:$ no $-\equiv \mathrm{Si}-\mathrm{H}$ absorption at 2169-2170; 1080 (三SiOSi $\equiv), 976,1359$ (C-F), 1171 $(\mathrm{CO}-\mathrm{O}), 1274,1409(\mathrm{Si}-\mathrm{C}), 1751(\mathrm{C}=\mathrm{O})$ and $2800-3100$ (C-H) [17-19].

${ }^{1} \mathrm{H}$ NMR $\left(d\right.$-DMSO, $\left.\mathrm{CCl}_{4}\right),(\mathrm{ppm}) \delta: 0.13(\mathrm{Si}-\underline{\mathrm{Me}})$; $1.2\left(\mathrm{~m}, \mathrm{Si}-\mathrm{CH}_{2}-\right.$ anti-Markovnikov addition); $0.9,1.6$ $\left(\mathrm{m},=\mathrm{CH}-\mathrm{CH}_{3}\right.$ Markovnikov addition); 0.9, 1.60 (m, $\left.=\mathrm{CH}-\mathrm{CH}_{3}\right) ; 1.64,2,4\left(\mathrm{~m},=\underline{\mathrm{CH}}-\mathrm{CH}_{3}\right) ; 2.4\left(\mathrm{~m}, \underline{\mathrm{CH}_{2}}-\mathrm{O}\right)$ overlaps with signals of methine $=\underline{\mathrm{CH}}-\mathrm{CH}_{3}$ groups; 4.7 (m, $\left.\mathrm{CH}_{2}-\mathrm{CF}_{2}\right) ; 6.0-6.8\left(\mathrm{~m}, \mathrm{CF}_{2} \underline{\mathrm{H}}\right.$ ).

${ }^{13} \mathrm{C}$ NMR ( $d$-DMSO, $\left.\mathrm{CCl}_{4}\right),(\mathrm{ppm}):-1.98 \quad(\mathrm{Si}-$ $\left.\mathrm{CH}_{3}\right), 7.9,8.8,18.2,26.6,27.1,107,107.8$ and $173 \mathrm{ppm}$ correspond to carbon nucleus in the group: $=\mathrm{CH}-\mathrm{CH}_{3}$, $=\underline{\mathrm{CH}}-\mathrm{CH}_{3}, \equiv \mathrm{SiCH} \mathrm{CH}_{2}-,-\mathrm{CH}_{2} \mathrm{CO}-,-\mathrm{CO}-\mathrm{CH}_{2}-\mathrm{CF}_{2}-$, $-\underline{\mathrm{CF}}_{2}-,-\underline{\mathrm{CHF}}_{2}$ and $\underline{\mathrm{C}}=\mathrm{O}$, respectively. ${ }^{29} \mathrm{Si} \mathrm{NMR}(\mathrm{ppm}):-$ 20.0 for $\mathrm{D}$ fragments.

The hydrosilylation reactions in the presence of other catalysts were carried out according to the same method.

\subsection{Ring-Opening Polymerization Reaction of $\mathrm{D}_{4}{ }^{\mathrm{R}}$}

$2.0000 \mathrm{~g}\left(1.4451 \cdot 10^{-2} \mathrm{~mol}\right)$ of $\mathrm{D}_{4}{ }^{\mathrm{R}}$ was transferred into a $50 \mathrm{ml}$ flask under nitrogen. High vacuum was applied to the flask for half an hour. Then the compound was dissolved in $1.8 \mathrm{ml}$ of dry toluene and $0.01 \%$ of total mass powder potassium hydroxide was added. The mixture was degassed, placed in an oil bath that was previously set to $363-383 \mathrm{~K}$, and polymerized under nitrogen for $25 \mathrm{~h}$. Then $7 \mathrm{ml}$ of toluene were added to the 
reaction mixture and the product was washed with water. The crude product was stirred with $\mathrm{MgSO}_{4}$ for 6 hours, filtered and evaporated; the oligomer was precipitated at least three times into pentane to remove side products. Finally, all volatiles were removed under vacuum up to constant mass, after that $1.84 \mathrm{~g}(92 \%)$ of colorless viscous oligomer (II) has been isolated. For oligomer II founded: $\eta_{s p}=0.1-0.14 ; T_{s o f}=312 \mathrm{~K} ; \quad \bar{M}_{n}=5.772 \cdot 10^{3}$; $\bar{M}_{\omega}=1.264 \cdot 10^{4}(\mathrm{D}=2.1)$.

FTIR $\left(\mathrm{KBr}, \mathrm{cm}^{-1}\right) v_{a s}:$ no $-\equiv \mathrm{Si}-\mathrm{H}$ absorption at 2169-2170; 1082 (三SiOSi $\equiv), 976,1360$ (C-F), 1172 $(\mathrm{CO}-\mathrm{O}), 1272,1403(\mathrm{Si}-\mathrm{C}), 1756(\mathrm{C}=\mathrm{O})$ and $2800-3100$ $(\mathrm{C}-\mathrm{H})$.

${ }^{1} \mathrm{H}$ NMR $\left(d\right.$-DMSO, $\left.\mathrm{CCl}_{4}\right)$, (ppm) $\delta: 0.13(\mathrm{Si}-\underline{\mathrm{Me}})$; $1.2\left(\mathrm{~m}, \mathrm{Si}-\mathrm{CH}_{2}-\right.$ anti-Markovnikov addition); 0.9, 1.6 (m, $=\mathrm{CH}-\mathrm{CH}_{3}$ Markovnikov addition $) ; 0.9,1.60(\mathrm{~m},=\mathrm{CH}-$ $\left.\underline{\mathrm{CH}}_{3}\right) ; 1.64,2,4\left(\mathrm{~m},=\underline{\mathrm{CH}}-\mathrm{CH}_{3}\right) ; 2.4\left(\mathrm{~m}, \underline{\mathrm{CH}} \underline{\mathrm{C}}_{2}-\mathrm{O}\right)$ overlaps with signals of methine $=\underline{\mathrm{CH}}-\mathrm{CH}_{3}$ groups; $4.7\left(\mathrm{t}, \mathrm{OC}_{\underline{2}}-\right.$ $\left.\mathrm{CF}_{2}\right) ; 6.0-6.8\left(\mathrm{t}, \mathrm{CF}_{2} \mathrm{H}\right)$.

${ }^{13} \mathrm{C} \mathrm{NMR}\left(d\right.$-DMSO, $\left.\mathrm{CCl}_{4}\right),(\mathrm{ppm}):-1.98 \quad(\mathrm{Si}-$ $\left.\mathrm{C}_{3}\right), 7.9,8.8,18.2,26.6,27.1,107,107.8$ and 173 ppm correspond to carbon nucleus in the group: $=\mathrm{CH}-\underline{\mathrm{CH}}_{3}$, $=\underline{\mathrm{CH}}-\mathrm{CH}_{3}, \equiv \mathrm{SiCH} \mathrm{CH}_{2}-,-\mathrm{CH}_{2} \mathrm{CO}-,-\mathrm{CO}-\mathrm{CH}_{2}-\mathrm{CF}_{2}-$, $\underline{\mathrm{C}} \mathrm{F}_{2-},-\underline{\mathrm{C} H F_{2}}$ and $\underline{\mathrm{C}}=\mathrm{O}$, respectively.

\subsection{General Procedure for Preparation of Cross-Linked Polymer Electrolytes}

$1.0000 \mathrm{~g}$ of the base compound $\mathbf{I}$ was dissolved in $4 \mathrm{ml}$ of dry THF and thoroughly mixed for half an hour. After that the required amount of lithium triflate from the previously prepared stock solution in THF was added to the mixture the stirring was continued for further $1 \mathrm{~h}$. The mixture was then poured onto a Teflon mould with a diameter of $4 \mathrm{~cm}$, then the catalytic amount of acid (one drop of $0.1 \mathrm{~N} \mathrm{HCl}$ solutions in ethyl alcohol) was added to initiate the cross-linking process and the solvent was allowed to evaporate slowly overnight. Finally, the membrane was dried in an oven at $343 \mathrm{~K}$ for 3 days and at $373 \mathrm{~K}$ for $1 \mathrm{~h}$. Homogeneous and transparent films with the average thickness of $200 \mu \mathrm{m}$ were obtained in this way. These films were insoluble in all solvents, except THF.

\subsection{AC Impedance Measurements}

The total ionic conductivity of samples was determined by locating an electrolyte disk between two $10 \mathrm{~mm}$ diameter brass electrodes. The electrode/ electrolyte assembly was secured in a suitable constant volume support which allowed extremely reproducible measurements of conductivity to be obtained between repeated heating-cooling cycles. The cell support was located in an oven and the sample temperature was measured by a thermocouple disposed close to the electrolyte disk. The bulk conductivities of electrolytes were obtained during a heating cycle using the impedance technique (Impedance meter BM 507-TESLA for the frequencies of $50 \mathrm{~Hz}-500 \mathrm{kHz}$ ) within a temperature range of 303-363 K.

\section{Results and Discussion}

For obtaining of $\mathrm{D}_{4}{ }^{\mathrm{R}}$ type compounds with octafluoropentyl propionate side groups we have studied hydrosilylation reaction of $\mathrm{D}_{4}{ }^{\mathrm{H}}$ with $2,2,3,3,4,4,5,5$ octafluoropentyl acrylate at 1:4.2 ratio of initial compounds in the presence of platinum catalysts (platinum hydrochloric acid, Karstedt's catalysts and $\mathrm{Pt} / \mathrm{C}$ ) at the temperatures of 343-363 K. Preliminary heating of initial compounds in the temperature range of $333-363 \mathrm{~K}$ in the presence of the catalyst showed that the polymerization of $\mathrm{D}_{4}{ }^{\mathrm{H}}$ with 2,2,3,3,4,4,5,5-octafluoropentyl acrylate, break of siloxane backbone, or elimination of methane do not take place under these conditions. There are no changes in the NMR and FTIR spectra of initial compounds.

The hydrosilylation reaction has been carried out in a melt condition and in a toluene solution. It was established that hydrosilylation reaction of $\mathrm{D}_{4}{ }^{\mathrm{H}}$ with 2,2,3,3,4,4,5,5-octafluoropentyl acrylate proceeds vigorously at the beginning stages for the first 3-7 min. For decreasing side reactions and for obtaining fully substituted cyclotetrasiloxanes $\left(\mathrm{D}_{4}{ }^{\mathrm{R}}\right)$ we have investigated hydrosilylation reactions of $\mathrm{D}_{4}{ }^{\mathrm{H}}$ with $2,2,3,3,4,4,5,5$ octafluoropentyl acrylate in a dry toluene solution (50$60 \%$ ) in the $343-353 \mathrm{~K}$ temperature range.

During the hydride addition reactions, the decrease of active $\equiv \mathrm{Si}-\mathrm{H}$ bonds concentrations in time via $\mathrm{FTIR}$ spectroscopy was observed. During hydrosilylation reaction of $\mathrm{D}_{4}{ }^{\mathrm{H}}$ with 2,2,3,3,4,4,5,5-octafluoropentyl acrylate the decrease of active $\mathrm{Si}-\mathrm{H}$ bond has been studied. It was found that in hydrosilylation reactions the used Karstedt's catalysts were characterized with the same reaction ability as platinum hydrochloric acid and their abilities are higher than that for $\mathrm{Pt} / \mathrm{C}$. The reaction proceeds according to the Scheme 1:

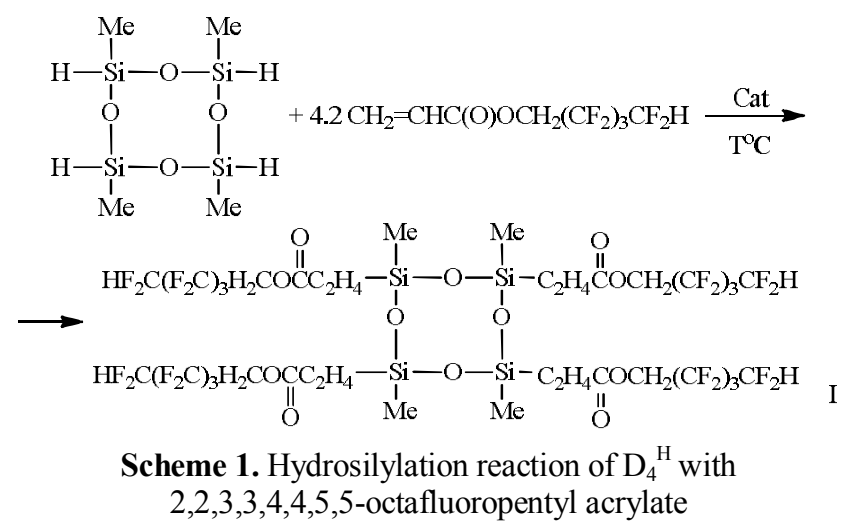


Table 1

Some physical chemical properties of organocyclotetrasiloxane

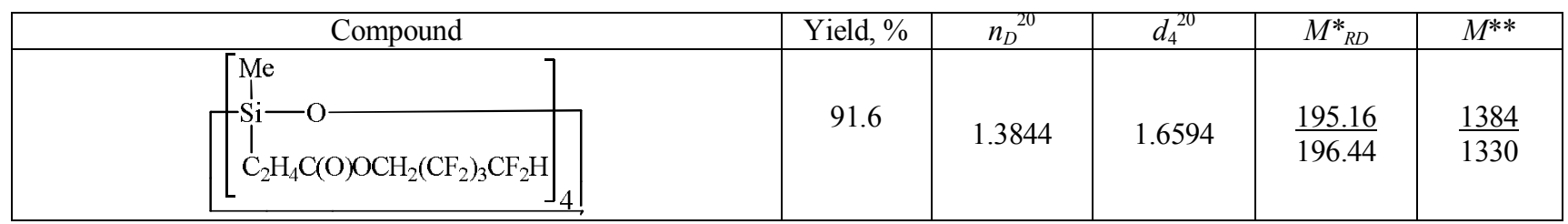

Notes: * for molecular refraction the calculated values are numerator, found values -denominator; ** molecular masses were determined via ebullioscopy method

The obtained compound $\mathbf{I}\left(\mathrm{D}_{4}{ }^{\mathrm{R}}\right)$ is a viscous, transparent product, well soluble in ordinary organic solvents (toluene, chloroform, benzene, etc). Its structure and composition were proved via elemental analysis, determination of molecular masses, molecular refraction, FTIR, ${ }^{1} \mathrm{H},{ }^{13} \mathrm{C}$ and ${ }^{29} \mathrm{Si}$ NMR spectral data. Some properties of compound I are represented in Table 1. It was studied that catalyst activity decreases in the following series: Karstedt's catalysts $\approx \mathrm{H}_{2} \mathrm{PtCl}_{6}>\mathrm{Pt} / \mathrm{C}$.
The polymerization reactions of $\mathrm{D}_{4}{ }^{\mathrm{R}}$ have been carried out in the presence of anhydrous powder-like potassium hydroxide or tetramethylammoniumfluoride ( $0.1 \mathrm{wt} \%$ of the cyclic compound total weight) at $363-$ $383 \mathrm{~K}$. When using potassium hydroxide as a catalyst the partially cross-linked polymers were obtained, which may be explained by the occurrence of hydrolytic condensation reactions of $\mathrm{CO}-\mathrm{O}$ groups. So, for obtaining soluble polymers we have used tetramethylammonium fluoride. The reaction proceeds according to the Scheme 2:
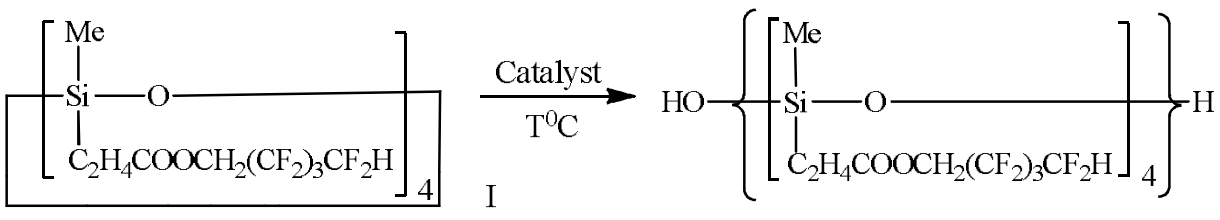

II, II', II"

Scheme 2. Polymerization reaction of compound I ( $363 \mathrm{~K}-\mathrm{II}^{1}, 373 \mathrm{~K}-\mathrm{II}^{2}$ and $\left.383 \mathrm{~K}-\mathrm{II}\right)$

Table 2

Some physico-chemical properties of polymer II

\begin{tabular}{|c|c|c|c|c|c|c|}
\hline Symbol & Yield, $\%$ & Polymerization temperature, K & Polymerization time, $\mathrm{h}$ & $\eta_{s p}$ & $T_{g}, \mathrm{~K}$ & $\bar{M}_{n}, \bar{M}_{\omega}, \mathrm{D}$ \\
\hline II & 92 & 383 & 33 & 0.14 & 313 & $5.772 \cdot 10^{3}, 1.264 \cdot 10^{4}, 2.19$ \\
\hline $\mathbf{I I}^{1}$ & 89 & 373 & 38 & 0.12 & - & - \\
\hline $\mathbf{I I}^{2}$ & 85 & 363 & 44 & 0.10 & - & - \\
\hline
\end{tabular}

The synthesized polymers are transparent, of viscous type and are well soluble in organic solvents with $\eta_{s p} \gg 0.11-0.14$. The structure and composition of obtained polymers were proved by FTIR, ${ }^{1} \mathrm{H},{ }^{13} \mathrm{C}$ and ${ }^{29} \mathrm{Si}$ NMR spectral analysis. Some physico-chemical properties of polymers are presented in Table 2.

The sol-gel reactions of polymer II were carried out. To obtain solid membranes the certain amounts of lithium salts, lithium trifluoromethanesulfonate (triflat) and lithium bis(trifluoromethanelsulfonyl)imide were added to the tetrahydrofuran solution of polymer II in a special Teflon vessel and stirred. The sol-gel reaction proceeds according to the Scheme 3:

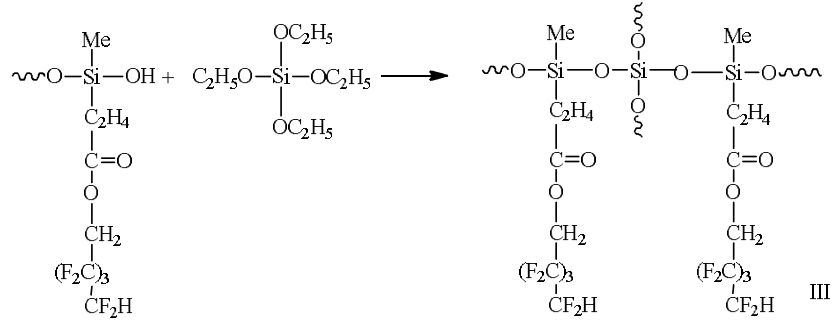

Scheme 3. Sol-gel reaction of polymer II

On the basis of polymer II the solid PE membranes III were obtained. In case of lithium triflat: III(1) $-5 \%$; III(2) $-10 \%$, III(3) $-15 \%$; III(4) - 20\%. And in case of 
lithium bis(trifluoromethanesulfonyl)imide: III(5) - 5\%, III(6) - 10\%, III(7) - 15\%; III(8) - 20\%.

For obtained solid PE membranes II FTIR investigations have been carried out. In FTIR spectra one can observe all signals which are characterized for polymer II. In FTIR spectra the intensity of absorption bands for non-associated $\equiv \mathrm{Si}-\mathrm{OH}$ bonds slightly rises. In the spectra we can see absorption bands characteristic for valence and fan shape oscillation for $\mathrm{C}-\mathrm{F}$ bonds at 1350 1353 and $1136-1141 \mathrm{~cm}^{-1}$, respectively.

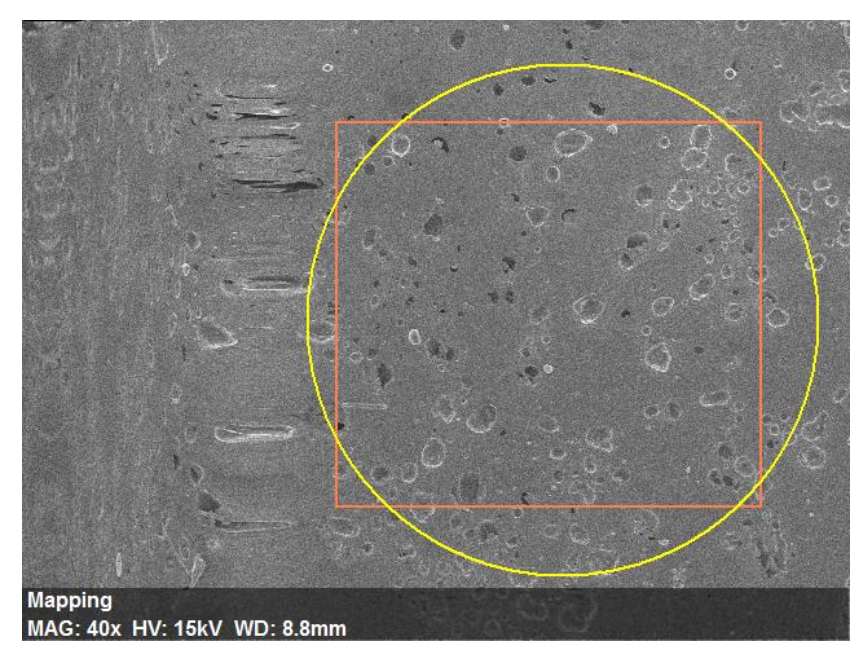

Fig. 1. SEM image of solid PE membrane III(2) with $10 \%$ of $\mathrm{CF}_{3} \mathrm{SO}_{3} \mathrm{Li}$ (Spectrum 1)

Surface morphology of solid PE membrane III(2) $\left(10 \%\right.$ of $\mathrm{CF}_{3} \mathrm{SO}_{3} \mathrm{Li}$ ) with a scanning electron microscope and energy dispersive $\mathrm{X}$-ray microscopic analysis method has been studied. The SEM image shows (Fig. 1) more or less smooth and uniform surface morphology of membrane, which confirms the full amorphous nature of polymer electrolyte membrane and the full solubility of lithium salt in the matrix. Image shows the full dispersion of triflat and small pores that causes fast ion movement. Soups are well visible amorphous layers of lithium salts, which also lead to higher ion motion.

The X-ray energy dispersive microscopic spectral analysis of solid PE membranes III shows approximately homogeneous composition of the obtained membranes (Fig. 2).

For solid PE membranes, DSC investigations have been carried out. It was determined that the glass transition temperature of membranes changes in 181.1$181.3 \mathrm{~K}$ temperature range, and the softening temperature changes within $293.3-320 \mathrm{~K}$.

Thermogravimetric investigations of solid $\mathrm{PE}$ membranes have been carried out. It is obvious from thermogravimetric curves that for membranes $5 \%$ the mass loss is observed in the range of $473-485 \mathrm{~K}$, that is probably related to the allocation of gas type products. The main destruction process proceeds in the range of 493-753 K.

For the solid polymer electrolytic membranes ionconductivity was determined at room temperature and $363 \mathrm{~K}$ by the impedance spectroscopic method. The values of ion-conductivity of the membranes are presented in Table 2.

The temperature dependences of membranes III containing $\mathrm{CF}_{3} \mathrm{SO}_{3} \mathrm{Li}$ and $\left(\mathrm{CF}_{3} \mathrm{SO}_{2}\right)_{2} \mathrm{NLi}$ in Arrhenius coordinates are represented in Figs. 3 and 4. The curves indicate the level of conductivity changes for these membranes.

Conductivity essentially depends on the material content and their concentration. The peculiarity of this dependence is expressed in extreme character of the corresponding curves, i.e. appearance of the maxima at definite concentrations of the salts. Above it was noted that the reason of the maximum appearance is in appearance of the ionic pairs at relatively high concentrations of the salts, the mobility of which is lower in comparison with single ions and, consequently the density of electric current for membranes containing relatively high concentrations of salts is lower than for membranes with reduced concentrations of salts. For membranes containing about $10 \mathrm{wt} \%$ of the salts we observed the maxima on the concentration curves of the membranes. Such character of the polymer membranes conductivity dependence is in a good agreement with known experimental data and explains conductivity arising (decreasing of charge transfer phenomenon due to the formation of ion pairs with relatively low mobility at high concentration of the salts [20]). The experiments show that the temperature dependence of the electrolyte conductivity is more exactly described by known VogelTammann-Fulcher (VTF) formula [20]. In this case the curves have a straight-line form, which is more available for calculation of the activation energy.

The volt-ampere characteristics of the membranes (Figs. 5 and 6) were also studied. The curves are characterized with monotonic increasing and are linear till definite values of the parameters, but at more high voltages the curves bend and at further increasing of the voltage the curves reach their saturations. Deviations from the linear increase of intensity with voltage are partially related to charge-phonon interactions that are enhanced with increasing ion energy giving rise to a decrease of the electrolyte conductivity [21]. 


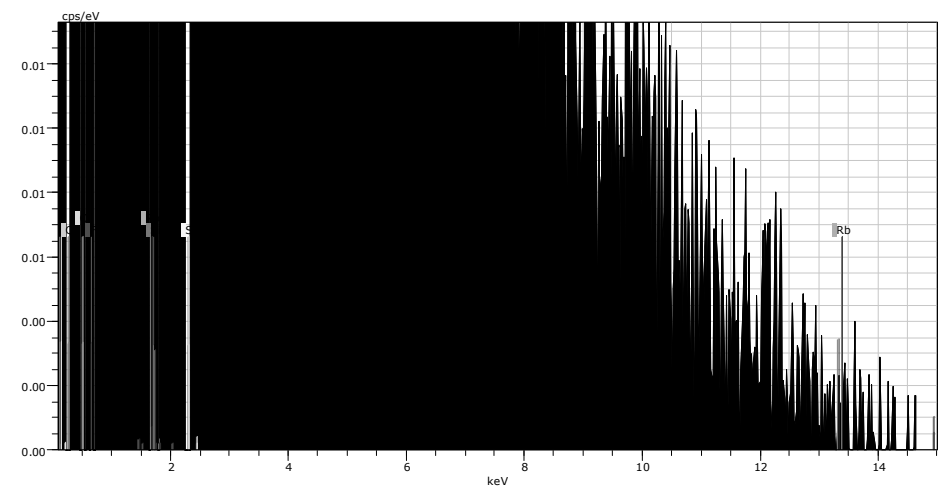

Fig. 2. Energy dispersive X-ray microscopic analysis of solid PE membrane III(2)

(Spectrum 1)

Table 2

Electric specific conductivity of membranes III

\begin{tabular}{|c|c|c|c|c|c|}
\hline $\begin{array}{c}\text { Membrane } \\
\text { III }\end{array}$ & Salt & $\begin{array}{c}\text { Salt } \\
\text { content, } \\
\text { wt \% }\end{array}$ & $\begin{array}{c}\text { Specific volum. electric } \\
\text { resistance at 298 K, } \\
\text { Ohm·cm }\end{array}$ & $\begin{array}{c}\text { Specific volum. electric } \\
\text { conductivity at 298 K, } \\
\text { S/cm }\end{array}$ & $\begin{array}{c}\text { Specific volum. electric } \\
\text { conductivity at 363 K, S/cm }\end{array}$ \\
\hline III(1) & $\mathrm{CF}_{3} \mathrm{SO}_{3} \mathrm{Li}$ & 5 & $1.7 \cdot 10^{9}$ & $5.9 \cdot 10^{-10}$ & $1.1 \cdot 10^{-8}$ \\
\hline III(2) & $\mathrm{CF}_{3} \mathrm{SO}_{3} \mathrm{Li}$ & 10 & $5.4 \cdot 10^{5}$ & $1.9 \cdot 10^{-6}$ & $1.2 \cdot 10^{-5}$ \\
\hline III(3) & $\mathrm{CF}_{3} \mathrm{SO}_{3} \mathrm{Li}$ & 15 & $1.4 \cdot 10^{7}$ & $2.0 \cdot 10^{-8}$ & $7.2 \cdot 10^{-6}$ \\
\hline III(4) & $\mathrm{CF}_{3} \mathrm{SO}_{3} \mathrm{Li}$ & 20 & $1.4 \cdot 10^{6}$ & $2.0 \cdot 10^{-7}$ & $1.1 \cdot 10^{-6}$ \\
\hline III(5) & $\left(\mathrm{CF}_{3} \mathrm{SO}_{2}\right)_{2} \mathrm{NLi}$ & 5 & $5.3 \cdot 10^{6}$ & $1.9 \cdot 10^{-7}$ & $3.0 \cdot 10^{-6}$ \\
\hline III(6) & $\left(\mathrm{CF}_{3} \mathrm{SO}_{2}\right)_{2} \mathrm{NLi}$ & 10 & $2.9 \cdot 10^{6}$ & $3.4 \cdot 10^{-7}$ & $9.6 \cdot 10^{-6}$ \\
\hline III(7) & $\left(\mathrm{CF}_{3} \mathrm{SO}_{2}\right)_{2} \mathrm{NLi}$ & 15 & $6.1 \cdot 10^{6}$ & $1.6 \cdot 10^{-7}$ & $9.2 \cdot 10^{-6}$ \\
\hline III(8) & $\left(\mathrm{CF}_{3} \mathrm{SO}_{2}\right)_{2} \mathrm{NLi}$ & 20 & $6.9 \cdot 10^{6}$ & $1.4 \cdot 10^{-7}$ & $5.9 \cdot 10^{-6}$ \\
\hline
\end{tabular}

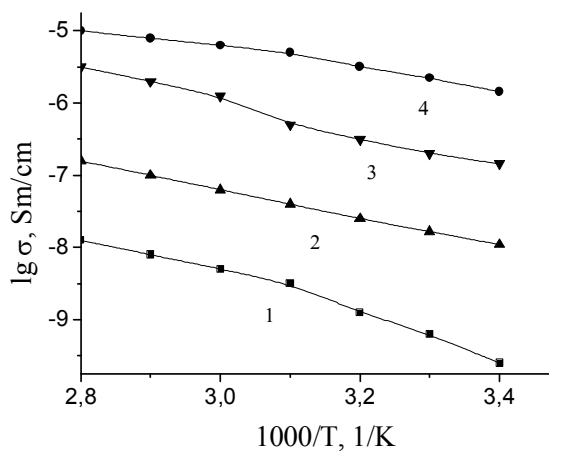

Fig. 3. Temperature dependence of membranes III(1-4) (with $\mathrm{CF}_{3} \mathrm{SO}_{3} \mathrm{Li}$ salt) in Arrhenius coordinates at salt concentrations (wt \%): 5 (1); 20 (2); 15 (3) and 10 (4)

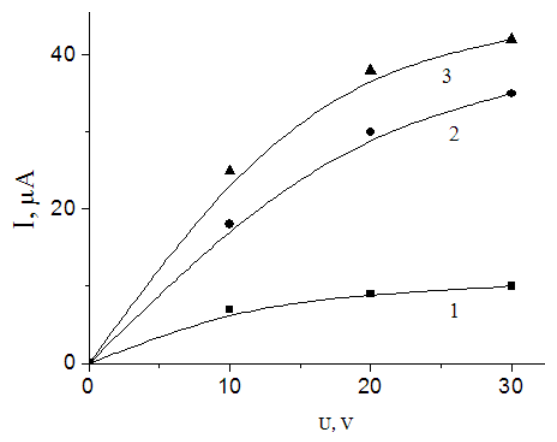

Fig. 5. Volt-ampere characteristics for membranes III(1-4) $\left(\mathrm{CF}_{3} \mathrm{SO}_{3} \mathrm{Li}\right.$ salt) at salt concentrations (wt \%): 5 (1); 20 (2) and $15(3)$

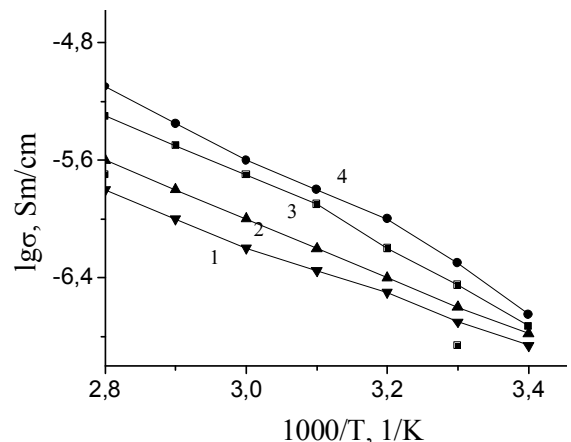

Fig. 4. Temperature dependence of membranes III(5-8) (with $\left(\mathrm{CF}_{3} \mathrm{SO}_{2}\right)_{2} \mathrm{NLi}$ salt $)$ in Arrhenius coordinates at salt concentrations (wt \%): 5 (1); 20 (2); 15 (3) and 10 (4)

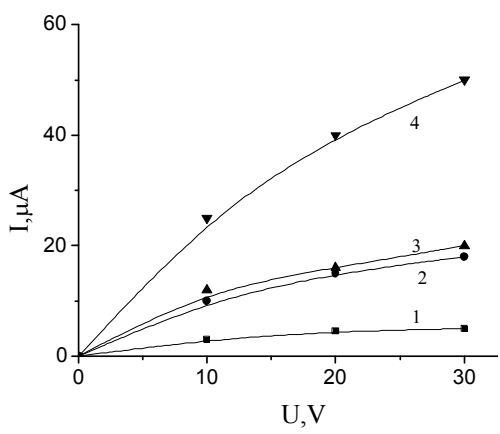

Fig. 6. Volt-ampere characteristics for membranes III(5-8) (with $\left(\mathrm{CF}_{3} \mathrm{SO}_{2}\right)_{2} \mathrm{NLi}$ salt) at salt concentrations (wt \%): 5 (1); 20 (2); 15 (3) and $10 \mathrm{wt} \%$ (4) 


\section{Conclusions}

The adduct $\mathrm{D}_{4}{ }^{\mathrm{R}}$ have been obtained at $353 \mathrm{~K}$ via hydrosilylation reaction of $\mathrm{D}_{4}{ }^{\mathrm{H}}$ with $2,2,3,3,4,4,5,5$ octafluoropentyl acrylate in the presence of platinum catalysts. The $\mathrm{D}_{4}{ }^{\mathrm{R}}$ comb-type polymers with $2,2,3,3,4,4,5,5$-octafluoropentyl propionate side groups have been obtained via polymerization. The structure and composition of $\mathrm{D}_{4}{ }^{\mathrm{R}}$ and polymers were determined using FTIR and NMR spectral data.

Sol-gel reactions of polymers doped with lithium trifluoromethanesulfonate (triflat) or lithium bis(trifluoromethanesulfonyl)imide have been studied and solid polymer electrolyte membranes have been obtained.

Dependence of the membranes conductivity on the salt concentration has extreme maximum character. This phenomenon is the result of two processes combination: the increase of ion-conductivity due to the increase of ion particles and formation of so-called ion pairs at relatively high concentrations of the salt, the mass of which is higher than that for mono-ions and consequently is characterized with lower mobility and low conductivity. The temperature dependences of membranes conductivity (in Arrhenius coordinates) reflect the known phenomenon of increasing the membranes conductivity as the result of enhancing charge particles mobility at increased temperatures.

\section{Acknowledgments}

The financial support of the Georgian National Science Foundation STCU-2016-16, Science and Technology Centre in Ukraine, Grant \# STCU 6301, is gratefully acknowledged.

\section{References}

[1] Di Noto V., Lavina S., Giffin G. et al.: Electrochim. Acta, 2011, 57, 4. https://doi.org/10.1016/j.electacta.2011.08.048

[2] Armand M.: Solid State Ionics, 1983, 9-10, 745. https://doi.org/10.1016/0167-2738(83)90083-8

[3] Muldoon J., Bucur C., Boaretto N. et al.: Polym. Rev., 2015, 55, 208. https://doi.org/10.1080/15583724.2015.1011966

[4] Baudry P., Lascaud S., Majastre H., Bloch D.: J. Power Sources, 1997, 68, 432. https://doi.org/10.1016/S0378-7753(97)02646-3

[5] Kerr J.: Polymeric Electrolytes: an Overview [in:] Nazri G., Pistoia G. (Eds.), Lithium Batteries. Springer US, Boston, MA 2003, 575-622.

[6] Sun C., Liu J., Gong Y. et al.: Nano Energy, 2017, 33, 363. https://doi.org/10.1016/j.nanoen.2017.01.028

[7] Goodenough J., Kim Y.: Chem. Mater., 2010, 22, 587. https://doi.org/10.1021/cm901452z
[8] Yue L., Ma J., Zhang J. et al.: Energy Storage Mater., 2016, 5, 139. https://doi.org/10.1016/j.ensm.2016.07.003

[9] Ben Youcef H., Garcia-Calvo O., Lago N. et al.: Electrochim. Acta, 2016, 220, 587.

https://doi.org/10.1016/j.electacta.2016.10.122

[10] Kang Y., Lee W., Hack Suh D., Lee C.: J. Power Sources,

2003, 119-121, 448e. https://doi.org/10.1016/S0378-

7753(03)00189-7

[11] Nugent J., Moganty S., Archer L.: Adv. Mater., 2010, 22, 3677. https://doi.org/10.1002/adma.201000898

[12] Saikia D., Wu H., Lin C. et al.: Polymer, 2012, 53, 6008.

https://doi.org/10.1016/j.polymer.2012.11.012

[13] Pan Y., Saikia D., Fang J. et al.: RSC Adv., 2014, 4, 13293.

https://doi.org/10.1039/C3RA47695B

[14] Chu Y., Liu Z., Saikia D. et al.: Ionics, 2015, 21, 2523.

https://doi.org/10.1007/s11581-015-1425-z

[15] Yuan W., Shen T., Liu X., Ren J.: Mater. Lett., 2013, 111, 9. https://doi.org/10.1016/j.matlet.2013.08.062

[16] Iwahara T., Kusakabe M., Chiba M., Yonezawa K.: J. Polym. Sci. A, 1993, 31, 2617.

https://doi.org/10.1002/pola.1993.080311023

[17] https://en.wikipedia.org/wiki/Infrared

[18] Socrates G.: Infrared and Raman Characteristic Group Frequencies: Tables and Charts. John Wiley\&Sons 2001.

[19] Stuart B.: Infrared Spectroscopy: Fundamentals and Applications. John Wiley\&Sons 2004.

[20] Zhang L., Zhang Z., Harring S. et al.: J. Mater. Chem., 2008, 18, 3713. https://doi.org/10.1039/B806290K

[21] Ziman J.: Principles of the Theory of Solids. Cambridge University Press 1964.

Received: May 27, 2019 / Revised: August 06, 2019 / Accepted: November 22, 2019

\section{ТВЕРДІ ПОЛІМЕР-ЕЛЕКТРОЛІТНІ МЕМБРАНИ НА ОСНОВІ ФЛУОРОСИЛОКСАНОВОЇ МАТРИЦІ}

\begin{abstract}
Анотаиія. Досліджено реакиї гідросилювання 2,4,6,8тетрагідро-2,4,6,8-тетраметилциклотетрасилоксана $\left(D_{4}^{H}\right)_{3}$ 2,2,3,3,4,4,5,5-октафлуоропентил акрилатом у співвідноменні 1:4,2 в присутності платинового каталізатора и одержано відповідний адукт $\left(D_{4}{ }^{R}\right)$. В присутності безводного гідроксиду калию проведено полімеризацію $D_{4}^{R}$, внаслідок чого отримано відповідний комб-полімер з бічними групами 2,2,3,3,4,4,5,5октафлуоропентил пропіонату. Синтезований продукт та полімери проаналізовано за допомогою методів Фур “с-спектроскопї, ${ }^{1} \mathrm{H},{ }^{13} \mathrm{C} i{ }^{29} \mathrm{Si}$ спектроскопї. Тверді полімер-електролитні мембрани одержані за допомогою золь-гель реакиій полімерів з тетраетоксисиланом, допованим трифлуорометансульфонатом літію (трифлат) та біс (трифлуорометансульфонил)імідом літію. Встановлено, щьо електропровідність полімер-електролітних мембран за кімнатної температури знаходиться в межах $\left(1,9 \cdot 10^{-6}\right)-5,9 \cdot 10^{-10} \mathrm{Cm} / \mathrm{cm}$.
\end{abstract}

Ключові слова: гідросилювання, полімеризачія, зольгель реакиії, тверді полімер-електролитні мембраны, спектроскопія, йонопровідність. 